\title{
養生中の温度および湿度が, フライアッシュを
}

\section{用レたコンクリートの強度におよ仿す影響}

\author{
正員左右田孝男* \\ 正員山崎寬司**
}

\section{EFFECT OF TEMPERATURE AND HUMIDITY DURING CURING ON STRENGTH OF CONCRETE CONTAINING FLY ASH}

By Takao Soda, C.E. Member, and Kanji Yamazaki, C.E. Member

Synopsis: The effects of curing conditions on the strength of concrete containing fly ash were studied. As a result, it has been found out that the curing conditions, such as the variation of curing temperature and relative humidity, have some influence upon the strength of concrete containing or not containing fly ash in the same way. If the proportion of concrete is designed reasonably, the use of fly-ash is often advantageous for the strength of concrete.

要 旨 フライアッシュを用いたコンクリートの強度を, 養生温度および養生湿度をいろいろに変えて試験 し，フライアッシュを用いないコンクリートの強度と比較した。コンクリートはフライアッシュを用いた場合も フライアッシュを用いない場合も, 標準養生の材令 28 日の強度が等しくなるように, 配合を決めた。したがっ てフライアッシュを用いたコンクリートでは，フライアッシュを用いない場合にくらべ単位セメントフラィア ッシュ量が増加している。てのように配合を決わた場合, 養生温度および湿度がコンクリートの強度におよぼす 影響は, フライアッシュを用いた場合も, フライアッシュを用いない場合も同程度であり, 条件によっては, フ ライアッシュを用いた方がより高い強度を示す場合のあるととが示された。

\section{1. 緒言}

フライアッシュを混合使用したコンクリートが工事現場において温度, 湿度の一定でない養生条件の下におか れたときの強度の発現に関してはまだ疑問の点が多い。とのためほかの混合セメントを用いる場合の注意と同様 フライアッシュを用いる場合には，乙れを用いない場合にくらべて，湿潤養生の期間を長くするなど特に慎重な 養生が望まれている。しかしダム以外の舗装あるいは一般土木構造用コンクリートにフライアッシュを用いた場 合の養生条件の影響に関する研究は，てれまでほとんど行なわれなかったようである。

このような問題を検討するため養生温度を $5^{\circ} \mathrm{C}, 20^{\circ} \mathrm{C}, 30^{\circ} \mathrm{C}$ と変えた場合，および 水中養生の期間を 0 日， 2 日，6日，13 日，27 日と変え以後空中に放置して乾燥養生を行なった場合の圧縮強度および曲げ強度を武験 し，フライアッシュを用いた場合と用いない場合の差異を比較した。

試験に用いたコンクリートの配合はフライアッシュを用いた場合に用いない場合とスランプおよび材令 28 日 压縮強度 $\left(20^{\circ} \mathrm{C}\right.$ 水中養生) が同じになるように選んだ。フライアッシュの使用が最初主としてダムコンクリー トの分野で発達したためセメントの一部をフライアッシュで置き換えて使用されることが多いが，初期材令の強 度を目標に配合設計する方法は, 舖装コンクリートおよび一般土木構造用コンクリートの実際にそくした方法で あって，てれによってダム以外の用途のコンクリートにフライアッシュを用いる場合の参考となる試験結果を得 るととができた。

本試験は土木学会フライアッシュ小委員会の共同研究の一部として行なわれ，なお試験には小委員会の配布し た共通試料のうち品質のかなり相違する 4 種のフライアッシュを用い, その平均值をもって比較検討したのでフ ライアッシュの一般的傾向を示す結果が得られたものと思われる。

\section{2. 実 験 方 法}

(1) 使 用材 料

（a）セメント 普通ポルトランドセメントを用いた。 
（b）フライアッシュ 土木学会フライアッシュ小委員会が共通陚料として配布した市販フライアッシュ4種 類を用いた。

JIS A 6201 による試験の結果は表一1 に示すとおりである。4 種類のフライアッシュの間にはかなり品質の 表一1 用いたフライアッシュの性質

\begin{tabular}{|c|c|c|c|c|c|c|c|c|c|c|c|}
\hline \multirow{2}{*}{ 種 類 } & \multirow{2}{*}{$\begin{array}{c}\text { 強熱減量 } \\
(\%) \\
\end{array}$} & \multirow{2}{*}{$\begin{array}{c}\text { 湿 }{ }^{\text {分 }} \\
(\%)\end{array}$} & \multirow{2}{*}{$\begin{array}{c}\Sigma{ }^{j}{ }^{j}{ }^{\circ} \\
\mathrm{SiO}_{2} \\
(\%)\end{array}$} & \multirow{2}{*}{ 比 } & 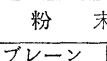 & \multirow{2}{*}{$\frac{\text { 度 }}{44 \mu}$} & \multirow{2}{*}{ 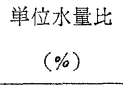 } & 压 縮 & \multicolumn{2}{|c|}{ 岶 強 度 } & 比 \\
\hline & & & & & $\begin{array}{l}\text { プーン } \\
\left(\mathrm{cm}^{2} / \mathrm{g}\right)\end{array}$ & & & 7 日 & 28 日 & & 91 日 \\
\hline A & 0.95 & 0.22 & 60.44 & 2.03 & 3500 & 11.9 & 94 & 73 & 78 & & 100 \\
\hline B & 1.17 & 0.41 & 55.94 & 2.41 & 3500 & 1.9 & 91 & 87 & 87 & & 108 \\
\hline C & 1.59 & 0.18 & 53.76 & 2.17 & 3410 & 14.9 & 95 & 68 & 72 & & 93 \\
\hline D & 1.09 & 0.19 & 61.08 & 2.11 & 3150 & 18.3 & 97 & 63 & 67 & & 83 \\
\hline
\end{tabular}

差が認められる。例えば単位水量比は最大 $97 \%$ (Dフライアッシュ), 最小 $91 \%$ (Bフライアッシュ) であり, 材令 91 日 の圧縮強度比は 83〜108\% の範囲に変化している。しかしいずれのフライアッシュも JIS の規定に 合格するものである。

(c) 骨材 粗骨材，細骨材とも相模川産のものを用いた。いずれもふるい分けたものを所定の粒度（細骨材 F.M $=2.82$ ，粗骨材 F.M =6.95）となるよう合成し，表面乾燥飽和状態で使用した。

\section{（2）コンクリートの配合}

次の条件を満足するようにコンクリートの配合を定めた。

(a) 骨材最大寸法…………...25 mm

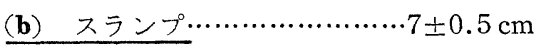

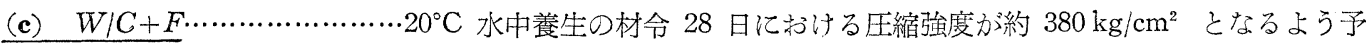
備実験を行なって定めた。

(d) $F / C+F$ (フライアッシュの混合割合) $25 \%$

その結果は 表一2 亿示すとおりである。フライアッシュ芠用いた場合と用いない場合の材令 28 日における圧 表-2 コンクリートの配 合

\begin{tabular}{|c|c|c|c|c|c|c|c|c|c|c|c|}
\hline \multirow{2}{*}{ No. } & 用いたフラ & $F / C+F$ & $W \mid C+F$ & $S \mid A$ & スランプ & \multicolumn{6}{|c|}{ 諸 材 料 の 単 位 量 $\left(\mathrm{kg} / \mathrm{m}^{3}\right)$} \\
\hline & イアッシュ & $(\%)$ & $(\%)$ & (\%) & $(\mathrm{cm})$ & $C+F$ & $c$ & $F$ & $W$ & $s$ & $G$ \\
\hline 1 & なし & 0 & 55.0 & 42.5 & 7.5 & 291 & 291 & 0 & 160 & 830 & 1150 \\
\hline 2 & A & 25 & 43.0 & 41.0 & 7.5 & 350 & 262 & 88 & 150 & 774 & 1145 \\
\hline 3 & B & 25 & 41.5 & 39.5 & 7.5 & 350 & 262 & 88 & 145 & 760 & 1192 \\
\hline 4 & $\mathrm{c}$ & 25 & 43.4 & 39.8 & 7.5 & 350 & 262 & 88 & 152 & 773 & 1200 \\
\hline 5 & D & 25 & 43.7 & 39.5 & 7.5 & 350 & 262 & 88 & 153 & 745 & 1170 \\
\hline
\end{tabular}

縮強度を等しくするような配合設計の方法は平野，北条がくわしく報告している

今回の試験では都合によりフライアッシュ C を用いた場合の配合をその 28 日圧縮強度 $\left(20^{\circ} \mathrm{C}\right.$ 水中養生) が フライアッシュを用いない場合と等しくなるように定めた。フライアッシュ A, B および $\mathrm{D}$ を用いた場合の配合 は，てれと単位セメント量および単位フライアッシュ量を同じにし，同じスランプを得られるような単位水量を 試し練りによって決定した。したがって各フライアッシュについて，W/C+Fが若干相違し $20^{\circ} \mathrm{C}$ 水中養生を行

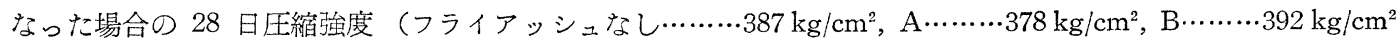
$\left.\mathrm{C} \cdots \cdots \cdots \cdot \cdots \cdot 372 \mathrm{~kg} / \mathrm{cm}^{2}, \mathrm{D} \cdots \cdots \cdots \cdot 369 \mathrm{~kg} / \mathrm{cm}^{2}\right)$ の間にも若干の差が認められる。しかし試験誤差を考えれば大体同じ 品質のコンクリートになるような配合が決定できたといえよう。

てれらの配合をさらにくわしく見ると単位水量はBフライアッショを用いた場合が $145 \mathrm{~kg} / \mathrm{m}^{3}$ でほかの 3 種類 にくらべていちじるしく減少が大きい。てのため強度もほが比して若干高い結果を示したものと思われる。

\section{(3) 強 度 試 験}

(a) 試験の種類……圧縮強度試験および曲げ強度試験

(b) 材令……3 日, 7 日，14日，28 日，91日，182日

(c) 供 試 体………縮強度 $\phi 10 \times 20 \mathrm{~cm}$ 円柱供試体 曲げ強度 $10 \times 10 \times 40 \mathrm{~cm}$ はり供試体

おのおの 1 試験条件, 1 材令に 3 本ずつ

（4）養生条件

(a) 養生温度に関する試験 
$5^{\circ} \mathrm{C}$

$\left.\begin{array}{l}20^{\circ} \mathrm{C} \\ 30^{\circ} \mathrm{C}\end{array}\right\}$ 水中養生

(b) 水中養生期間の変化に関する試験

(1)眖型後ただちに空中養生

(2)脱型後 2 日間水中養生以後空中養生

(3) ”6 6 日間

(4) ” 13 日間

(5) ”27日間

成形後 24 時間で脱型した。養生温度は水中，空中のいずれも $20^{\circ} \mathrm{C}$ であった。また空中養生を行なった恒温 室の湿度は R.H 60 80\% であった。空中養生を行なった供試体は強度試験のまえにふたたび水中に浸けること なくそのまま試験を行なった。

\section{3. 養生温度の影響}

養生温度を $20^{\circ} \mathrm{C}, 5^{\circ} \mathrm{C}, 30^{\circ} \mathrm{C}$ (いずれも水中養生) とした場合の材令と圧縮強度の関係は 図一1, 図一2, および 図-3 亿示すとおりであり，同じく材令と曲げ強度の関係は 図一

てれらの図において実線はフライアッシュを用いない場合（すなわち配合 No. 1 のコンクリート）の強度 を，点線は $\mathrm{A}, \mathrm{B}, \mathrm{C}$ およびDの 4 種のフライ アッシュをそれぞれ用いたコンクリートの平 均強度を示している。また図中各材令におけ る縦の太線は $\mathrm{A}, \mathrm{B}, \mathrm{C}, \mathrm{D} 4$ 種のフライアッシ ュを用いた場合の強度の最大值と最小值の範 因を示している。

4 種のフライアッシュの間の強度の差はこ の太線からわかるようにあまりいちじるしく ない。それでこれらの平均值を代表としてフ ライアッシュを用いたコンクリートの一般的 傾向を論ずることにする。

長期材令における強度の増加が大きいとと はフライアッシュの長所として従来よりいわ れてきたのであるが養生温度 $20^{\circ} \mathrm{C}$ とした 図 一1 の結果はこの性質を明瞭に示すものであ る。すなわちフライアッシュを用いない場合 26週における強度は 4 週における強度の $11 \%$ 増加しているに過ぎないが，フライアッシュ を用いた場合は約60\%の増加を示している。

低温度 $\left(5^{\circ} \mathrm{C}\right.$, 図一 2$)$ においてはフライアッ シュを用いたコンクリートの強度発現は用い ない場合に比して少しも劣ることなく材令が 長期になるほどフライアッシュを用いた方が 有利となるととがわかる。

すなわち低温においてもフライアッシュを 用いるととの利点は長期材令においてよと発 揮されるのである。

高温度 $\left(30^{\circ} \mathrm{C}\right.$, 図一3) においてはフライア ッシュを用いることの効果は材令 1 週頃より 現われており材令 4 週においてすでに用いな い場合上り $25 \%$ 程度高い強度を示している。

\section{図一1 養生温度 $20^{\circ} \mathrm{C}$ (水中) における材令と圧縮強度の関係}

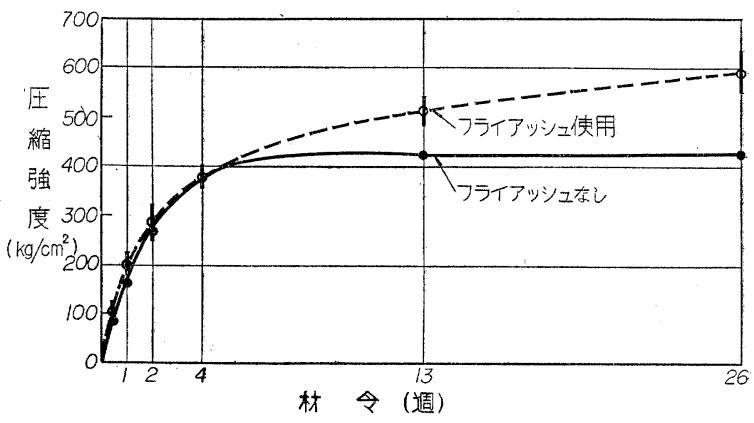

図一2 養生温度 $5^{\circ} \mathrm{C}$ (水中) における材令と圧縮強度の関係

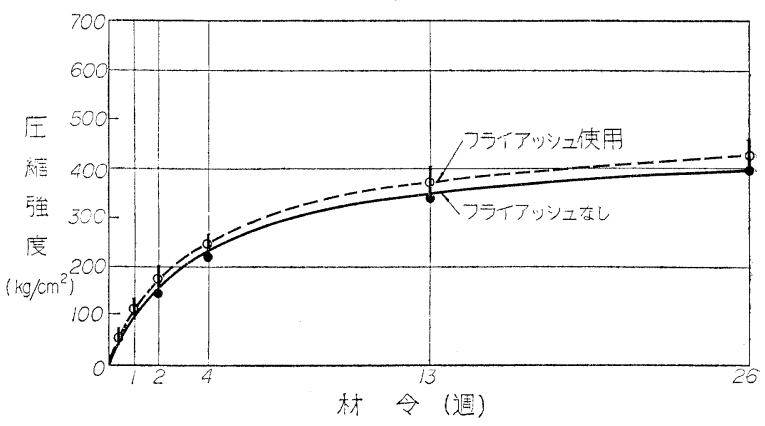

図一3 養生温度 $30^{\circ} \mathrm{C}$ (水中) における材令と压縮強度の関係

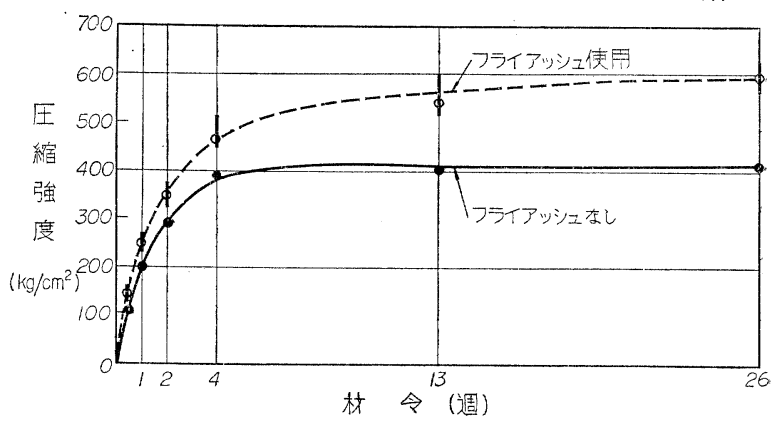


また用いない場合が 4 週以降ほとんど強度の 増加を示さないのに対し用いた場合はさらに 着実な增加を続け 26 週においては両者の間 に $50 \%$ 程度の差異を生しるに至っている。

曲げ強度に関しても圧縮強度の場合と同様 の傾向が認められフライアッシュを用いたコ ンクリートが養生温度によらず長期材令にい たるまですぐれた強度増加を続けることが示 された。特に異なった点はフライアッシュを 用いたコンクリートが用いないものに比して 压縮強度が同一になるよう配合を定めたにも かからわず曲げ強度が 10\% 高いことであ。 て，フライアッシュを用いたコンクリートの 曲げ強度がすぐれていることを示している。 また曲げ強度では養生温度の影響が圧縮強度 より少なく低温養生でも影響されることが少 ない。

以上のように材令 28 日の圧縮強度か㩐し くなるように配合を定めた場合フライアッシ ユを用いたコンクリートの強度は養生温度の 低いときにも，フライアッシュを用いない場 合に比していずれの材令でも劣ることなく， 養生温度が高いときにはフライアッシュの効 果が初期材令のうちから現われ，かえって高 心強度を示す結果がえられた。

\section{4. 水中養生期間の影響}

2.（4）汇記したように水中養生期間を変 えることによって生じる圧縮強度の変化は 図一7 (フライアッシュを用いないコンクリ ートの場合）および 図一8（フライアッシュ を用いた場合， 4 種の平均）に示すとおりで あった。との場合も養生温度に関する実験結果と同様に 4 種類のフライアッシュの間には若干のばらつきがあっ たがほとんど同じような傾向を示したので，乙れらの平均 值をもって一般にフライアッシュを用いたてとの影響を検 討するとととする。

水中養生の期間が長いほどフライアッシュを用いても用 いなくても強度の発現がよいととは従来いわれているとお りであるが，本実験のような方法でコンクリートの配合を 定めればフライアッシュを用いた場合の方がむしろ乾燥の影響が少ない結果が認められた。材令 26 週の強度に おいて水中養生 $\left(20^{\circ} \mathrm{C}\right) 28$ 日の圧縮強度を 100 とした指数值でくらべてみると表一 3 のようになる。

すなわちフライアッシュを用いない場合には 27 日間水中養生したのち乾燥を受けると材令 26 週に至って強 度が低下するのに反して，フライアッシュを用いた場合にはなお強度の増進が㦘められるのであって 13 日程度 の水中養生を行なえば以後空中に放置しても水中養生 4 週の强度より下まわらないととがわかった。

土木学会コンクリート標準示方書（無筋コンクリート 47 条）で沈打ち达み後，少なくとも 7 日間湿潤状態に 保たねばならないとしているが，フライアッシュを用いた場合もとの規定が満足されることが示された。

今回の実験のように材令 4 週における圧縮強度 $\left(20^{\circ} \mathrm{C}\right.$ 水中）およびスランプがフライアッシュを用いない場 
合と等しくなるような配合を定めてフライア ッシュ老使用すると用いない場合にくらべて 特に湿潤養生の期間を長くする必要はなく, か党って養生期間を短かくするてとも可能の ように思われる。フライアッシュのポゾラン 反応による強度の増加を十分に利用しょうと するためには長期間の湿潤養生が望ましいて とはいうまでもない。なお本試験全般につい て乾燥養生の影響が従来の結果とくらべて若 干大きく現われているが，乙れは供試体の寸 法が小さかったととによるものと思われる。

\section{5. 考察}

従来の研究によって高炉セメントやシリカ セメントのような混合やセメントは普通セメ ントにくらべて養生条件の影響を受けやすい ことが認められているが，上述のように本試 験の結果よりフライアッシュを混合して使用 したコンクリートはての影響を受けにくくほ かの混合セメントとは異なる性質を有するこ とが認められた。

フライアッシュをコンクリートに混合して 使用するとその成分中の可溶性シリカが徐々 にセメント水和によって生じた水酸化石灰と 化合し安定な珪酸石灰塩をつくるものと考え られる。ての反応によってコンクリートの強 度, 耐久性, 水密性などが改善されるのであ るが，フライアッシュは他のシリカ質混合材 そくらべて活性度が低いためてれらの効果は 長期材令に至らないと発現されない。また化 学分析の結果は材令の長期になっても遊離石 灰の量はあまり減少しておらず，ポゾラン反 応がフライアッシュ粒子のごく表面付近でし か起こらない緩慢な反応であることを示して いる。

写真一1，2 および 3 はフライアッシュ 25 \%を混合したセメントペーストの材令 4 週，

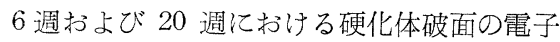
顕微鏡写真の代表的な一例であって，写真中 ほぼ球形な凸面または凹面はそれぞれフライアッシュ粒子, あるいはてれがペースト部分より引きはがされたあ とのフライアッシュとペーストの接触面を見たものである。

4 週程度の材令初期には 写真一1 の（a)，(b) 亿見られるようにフライアッシュにはほとんど 変化が認就ら れないが 6 週に至ると若干変化が生じ， 20 週ではての変化がかなり明瞭なものになっている。このようなフラ イアッシュの材令にともなう様相の変化はフライアッシュとセメント水和物との化学反応の進行に応じて生じる ものと考光られるのであって，4週以後の長期材令に至ってから徐々に反応が進行するととを実証するものと思 われる。フライアッシュを用いたコンクリートの強度が用いないものにくらへて養生条件の影響を孛しろ受けに くい性質を示したのは，4週以前の初期材令においてはまだポゾラン反応がほとんど起てらないととによるもの と考えられる。との武験のように材令 4 週の圧縮強度を目標に配合を定めてフライアッシュを用いると養生条件
(フライアッシュなし)

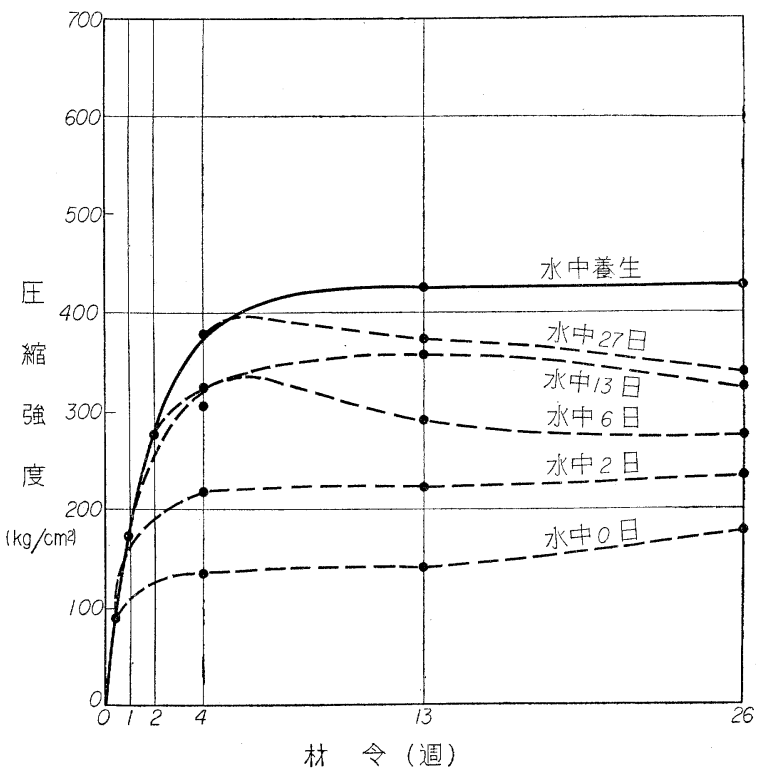

図一8＼cjkstart水中養生期間を変えた場合の圧縮強度の变化 （フライアッシュを用いた場合 4 種の平均）

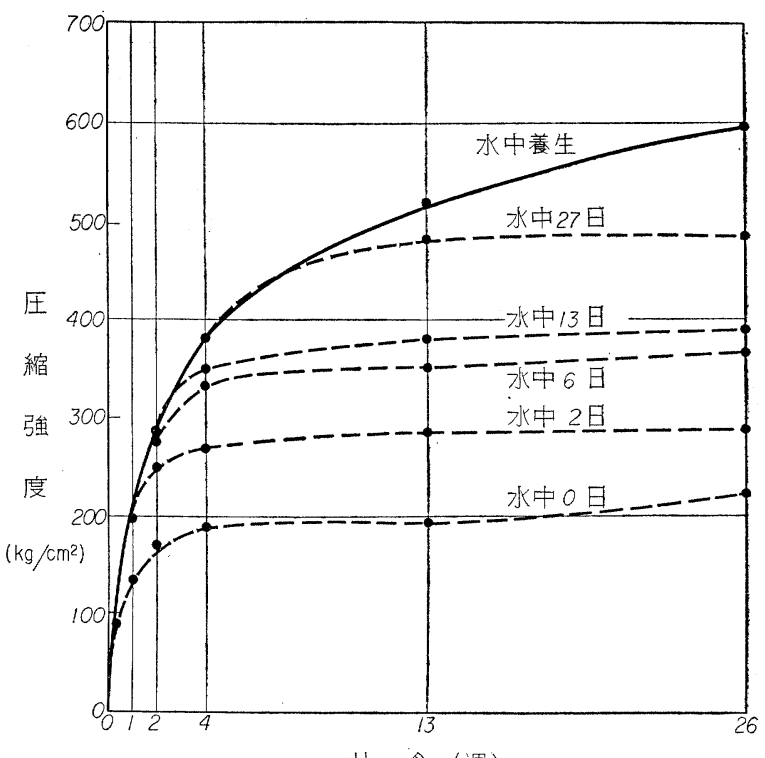

材令 (週) 
のいかんにかかわらず，4 週までの強 度は用いないものに劣ることなく，ポ ゾラン反応が進行を始める長期の材令 ではさらに強度が改善されることによ りフラィアッシュの使用が有利となる ものと思われる。

またフライアッシュを用いたコンク リートは $W / C+F$ は減少しているが $W / C$ は大きくなっており, 乾燥養生 でも強度の増進がよいのはこのためと 考えられる。同時にフライアッシュの 保水性なども関係しているのではない かと考えられる。

\section{6. 結 論}

従来フライアッシュを用いたコンク リートは養生温度が低い場合や, 乾燥 を受ける場合に強度の低下が大きいの ではないかという心配があり，このた め舗装コンクリートや一般土木構造用 コンクリートなと゚ダム以外の用途に用 いるととの可否か論ぜられていたが本 試験の結果より見て材令 28 日の王縮 強度が等しくなるように単位セメント ・フライアッシュ量を增してフライア ッシュを用いればフライアッシュを用 いたために湿潤養生の期間を特に長く する必要がないとと, 養生温度の高低 にかかわらずフライアッシニを用いな い場合とくらべて強度の発現は少しも おとることなく長期材令ではポゾラン 反応の效果がよく発現することが明ら かとなった。ダムなどのマスコンクリ 一ト以外の一般構造物のコンクリート そフライアッシュを用いる場合, コン クリートの配合を適切に選定するとと により，種々の養生条件においてフラ イアッシュを用いないコンクリートと 同程度または，それ以上の強度が得ら れ, しかもコンクリートの単位水量を 減し，乾燥収縮を少なくするなどのフ ライアッシュの利点を生かした品質の よいコンクリートが得られると考えら れる。

\section{写真一1 フライアッシュ混合ペースト硬化体破面の電子顕微鏡写真 倍率: 5000 倍 材令: 4 週 \\ $F / C+F: 25 \% \quad W / C+F: 36 \%$}

(a)

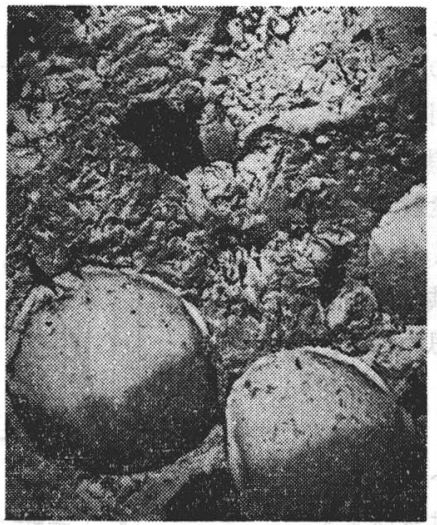

(b)

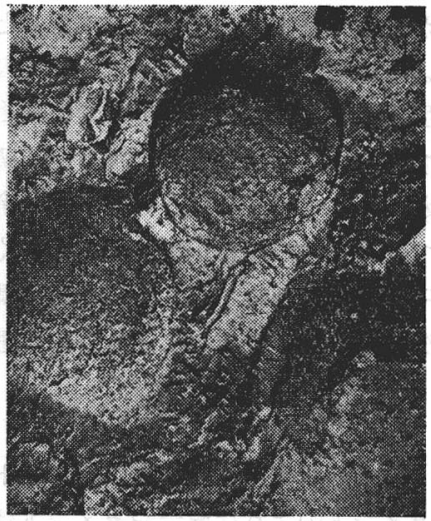

写真一2 フライアッシュ混合ペースト硬化体破面の電子顕微鏡写真 倍率: 5000 倍 材令: 6 週 (a)

(b)

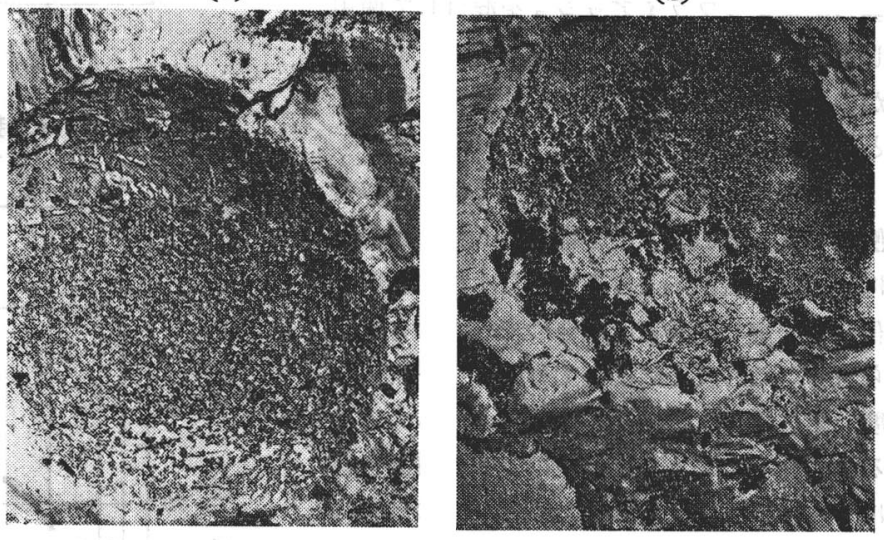

写真一3 フラィアッシュ混合ペースト硬化体破面の電子顕微鏡写真 倍率 : 5000 倍 材令 : 20 週 $F / C+F: 25 \% \quad W / C+F: 36 \%$

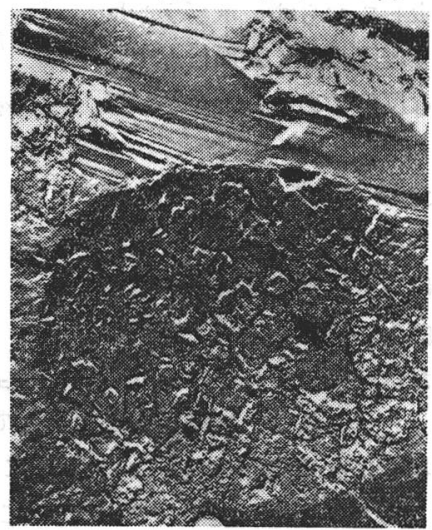

との研究に当り電子顕微鏡写真の提供を受けた佐治健治郎氏の厚意および武験を担当した村田研究員の努力に 厚く感謝の意を表する。

1）平野・北条: フライアッシニを用いた一般構造用コンクリートの配合設計方法，セメント技術年報昭和 32 年 